\title{
Michel Brix, Sainte-Beuve ou la liberté critique
}

\section{Lise Sabourin}

\section{(2) OpenEdition}

\section{Journals}

\section{Édition électronique}

URL : https://journals.openedition.org/studifrancesi/39653

DOI : 10.4000/studifrancesi.39653

ISSN : 2427-5856

\section{Éditeur}

Rosenberg \& Sellier

\section{Édition imprimée}

Date de publication : 1 décembre 2004

Pagination : 395

ISSN : 0039-2944

\section{Référence électronique}

Lise Sabourin, « Michel Brix, Sainte-Beuve ou la liberté critique », Studi Francesi [En ligne], 143 (XLVIII | II) | 2004, mis en ligne le 30 novembre 2015, consulté le 19 mai 2021. URL : http://

journals.openedition.org/studifrancesi/39653; DOI : https://doi.org/10.4000/studifrancesi.39653

Ce document a été généré automatiquement le 19 mai 2021.

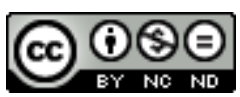

Studi Francesi è distribuita con Licenza Creative Commons Attribuzione - Non commerciale - Non opere derivate 4.0 Internazionale. 


\title{
Michel Brix, Sainte-Beuve ou la liberté critique
}

\author{
Lise Sabourin
}

\section{RÉFÉRENCE}

MICHEL BRIX, Sainte-Beuve ou la liberté critique, Jaignes, La Chasse au snark, 2002, pp. 89

1 Dans la petite collection de «Critique» heureusement instituée par l'éditeur La Chasse au snark, Michel Brix nous propose, parallèlement à la traduction de l'ouvrage de Wolf Lepenies la même année, un essai-synthèse en forme de réhabilitation du critique conspué par les années 1950. Il note d'emblée le regain récent d'études sur SainteBeuve et de publications, encore trop parcellaires, de ses œuvres critiques, pour en tirer la conclusion que, si le $\mathrm{XX}^{\mathrm{e}}$ siècle a accompli la première partie du programme proustien d'«oublier une chose pour la retrouver ensuite dans sa vérité», il reviendra peut-être au XXI ${ }^{\mathrm{e}}$ 'accomplir la seconde.

2 En cinq chapitres, Brix dégage les grandes tendances de la personnalité beuvienne et les met en parallèle avec celles de Hugo, Balzac, Baudelaire et Proust. Il rappelle d'abord comment «l'accoucheur d'âmes», le scrutateur exigeant ambitionnait de dégager de l'étude des individus créateurs la compréhension des familles d'esprits plutôt que de s'enfermer dans les dogmes génériques maintenus par Lemercier et Nisard ou dans le classement systématique de Taine, son élève discrètement renié.

3 L'indépendance intellectuelle, le refus des clans de ce rebelle sceptique émule de Montaigne expliquent peut-être, pense Brix, l'hostilité envers Sainte-Beuve du $\mathrm{XX}^{\mathrm{e}}$, «siècle d'utopies politiques, de catéchismes esthétiques et de doctrines absolues fondées sur la mise à l'écart voire la dissolution du sujet» (p. 43).

4 Au-delà du fossé sentimental creusé avec Hugo après 1831, Sainte-Beuve aurait surtout rejeté en l'auteur d'Hernani et des Chants du crépuscule le chef d'une pensée romantique qui avait imposé à ses œuvres de jeunesse son idéalisme prophétique. Au contraire, Baudelaire a su discerner dans les Poésies de Joseph Delorme la muse moderne d'un 
quotidien désenchanté; aussi Brix invite-t-il à relire la célèbre analyse du «Kamschatka» baudelairien comme une reconnaissance masquée d'une filiation gênante des «Fleurs du mal de la veille». De la même façon, Balzac, malgré la détestation personnelle de l'auteur de Louis Lambert envers de celui de Volupté, a revendiqué avoir voulu réécrire ce roman par le Lys: et Brix de rapprocher la technique critique beuvienne des «petits faits vrais» qui «représentent dans une entière vérité» de l'histoire naturelle des esprits embrassée par La Comédie humaine, tout aussi consciente de la modernité de son siècle.

Enfin Brix appelle à dépasser l'habituelle distinction du Contre Sainte-Beuve entre le moi profond et le moi social en considérant les aspects précurseurs de l'esthétique proustienne chez Sainte-Beuve. Appréhender le «livre intérieur des signes inconnus» dont l'œuvre artistique veut proposer la traduction, par un travail critique prenant conscience de soi à travers l'analyse d'autrui, relève effectivement d'une démarche similaire, même si le critique se propose de reconstituer la méthode créative d'un autre, tandis que l'auteur de la Recherche juge impossible d'exprimer l'intériorité d'un créateur à sa place.

6 Même si quelques pages (p. 47-49, voir aussi une formule contestable p. 66) reviennent sur la perception d'un romantisme étendu abusivement à l'ensemble du XIX $\mathrm{Xiècle}^{\mathrm{e}}$ (écueil du livre de Brix de 1999 sur Le Romantisme français. Eshétique platonicienne et modernité littéraire), cet essai réfléchit, avec liberté, sur le plus grand critique de ce siècle, trop longtemps condamné sans être lu, et invite à une nouvelle édition critique complète de son œuvre fort souhaitable. 